\title{
EFFECT OF ORGANOPHOSPHORUS COMPOUNDS ON ACETYLCHOLINE SYNTHESIS IN BRAIN
}

\author{
Makoto MURAMATSU and Kinya KURIYAMA \\ Department of Pharmacology, Kyoto Prefectural University of Medicine, \\ Kamikyo-kit. Kyoto 602. Japan \\ Accepted January 12, 1976
}

\begin{abstract}
Effects of parathion and di-isopropyl fluorophosphate (DFP) on acetylcholine (ACh) synthesis in the mouse brain were investigated. In addition to well known cholinesterase (ChE) inhibition, parathion showed inhibitory effects on the activity of synaptosomal choline acetyltransferase $(\mathrm{ChAc})$, and on the uptake of ${ }^{14} \mathrm{C}$ methylf-choline and $A C h$ synthesis in subcellular fractions of the brain. DFP inhibited ChE activity, but had no significant effects on the choline uptake and ACh synthesis per se. Possible significance of these findings in the pharmacological actions of organophosphorus compounds is briefly discussed.
\end{abstract}

It has been well established that organophosphorus compounds have an inhibitory effect on the activity of cholinesterase (ChE), but other pharmacological actions of these compounds remain unclear.

Hanin et al. (1) suggested the possibility that ChE inhibitors used at high concentrations may not alter the turnover rate of acetylcholine ( $\mathrm{ACh}$ ) solely by inhibiting $\mathrm{ChE}$. Kobayashi et al. (2) have also reported that diethyl-3, 2-dichlorovinyl phosphate (DDVP), one of the organophosphorus compounds, decreases $\mathrm{ACh}$ synthesis in the rat brain in vitro.

In the present study, not only the effect of parathion and DFP on ChE activity, but also effects of these drugs on the activity of choline acetyltransferase (ChAc) and on the uptake of choline in subcellular fractions from the mouse brain were examined.

\section{MATERIALS AND METHODS}

Male ddy mice weighing $20-30 \mathrm{~g}$ were used. For the separation of subcellular fractions, a $10 \%$ homogenate of whole brain with $0.32 \mathrm{M}$ sucrose was prepared in a glass homogenizer with Teflon pestle (Thomas type $B$ ). After separating nuclear $\left(P_{1}\right)$ fraction at $1,000 \times \mathrm{g}$ for $10 \mathrm{~min}$, crude mitochondrial $\left(\mathrm{P}_{2}\right)$ fraction was obtained by centrifuging at $12,000 \times \mathrm{g}$ for 30 min. Synaptosomal $\left(P_{2}-B\right)$ and microsomal $\left(P_{3}\right)$ fractions were obtained according to the procedure of Gray and Whittaker (3).

Enzymatic and chemical assay's: ChAc activity was determined according to the microassay procedure of Fonnum (4) using $\left[1^{-14} \mathrm{C}\right]$-acetyl CoA (S.A.: $3.7 \mathrm{mC} / \mathrm{m} \mathrm{mol}$ ). For kinetic studies, choline concentrations were varied for the range of concentrations of $0.085-10 \mathrm{mM}$. For assay blanks, choline was omitted from the reaction mixture. Synaptosomal fractions were ruptured hypotonically by suspending into $5 \mathrm{mM}$ phosphate buffer (pH 6.8) and used as an enzyme preparation. 
Acetylcholinesterase (AChE) activity was assayed according to the method of Ellman ct al. (5). Lactic dehydrogenase (LDH) activity and malic dehydrogenase (MDH) activities were determined respectively according to the method of Bergmeyer et al. (6) and Mehler e't al. (7). Protein content was determined by the method of Lowry ef al. (10).

Determination of Choline uptake and ACh synthesis: The crude mitochondrial $\left(\mathrm{P}_{2}\right)$ fraction suspended in $1 \mathrm{ml}$ of the Krebs-bicarbonate solution ( $\mathrm{pH} 6.8$ ) containing $0.1 \mathrm{mM}$ physostigmine sulfate (protein content: $2.3-5.7 \mathrm{mg} / \mathrm{ml}$ ) was used. After adding $10 / / \mathrm{M}$ (final concentration) of $\left[{ }^{1 \pm} \mathrm{C}-\right.$ methyl]-choline $(\mathrm{S} . \mathrm{A} .: 54.9 \mathrm{mC} / \mathrm{m}$ mol), the reaction mixture was incubated at $0 \mathrm{C}$ and $37^{\circ} \mathrm{C}$ respectively for $15 \mathrm{~min}$. Following the incubation, centrifuge tubes used for the reaction were chilled in ice and $1 \mathrm{ml}$ of ice cold $0.32 \mathrm{M}$ sucrose containing $1.0 \mathrm{mM}$ of unlabelled choline was added to each tube, and immediately centrifuged at $10.000 \therefore \mathrm{g}$ for $10 \mathrm{~min}$. The supernatant was transferred directly to a counting vial by decantation and the remaining pellet was transferred to a counting vial after solubilizing with hyamine. Radioactivities in the supernatant and solubilized pellet fractions were measured using a Packard Tri-carb scintillation spectrometer Model 3390.

Following the incubation of $\mathrm{P}_{2}$ fraction with $\left[{ }^{14} \mathrm{C}\right.$-methyl]-choline, the reaction mixture was centrifuged and [ ${ }^{1+} \mathrm{C}$-methyl]-ACh synthesized was also determined in both supernatant and pellet fractions. The $P_{2}$ pellets were suspended in $0.5 \mathrm{ml}$ of $1 \mathrm{~N}$ formic acid-acetone mixture $(15: 85(V / V))(8)$. After standing in crushed ice for $30 \mathrm{~min}$, each tube was centrifuged at $1,000 \times \mathrm{g}$ for $5 \mathrm{~min}$ and the supernatant was collected. After repeating these procedures twice, the combined supernatant was brought to a near dryness at $25^{\circ} \mathrm{C}$ and $0.5 \mathrm{ml}$ of methanol was added. On the other hand, the supernatant fractions obtained after the centri-

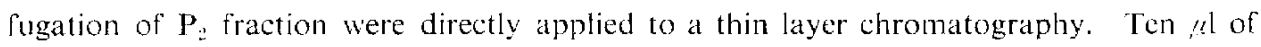
methanol suspension of the extract from pellet fractions and the supernatant fractions were applied respectively to thin layer chromatographic plate together with authentic choline and

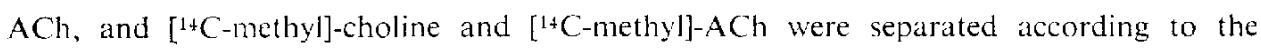
procedure described by Marchbanks (9). Butanol-ethanol-acetic acid-water mixture $(8: 2: 1: 3)$ was used for clution. Choline and $\mathrm{ACh}$ spots were identified by spraying the dry plate with iodoplatinate reagent (One part of aq. $5 \%$ (V/V)) chloroplatinic acid was added 1020 parts of $4.5 \%(\mathrm{~W} / \mathrm{V}) \mathrm{KI}$ in ethanol-water $(1: 1000(\mathrm{~V} / \mathrm{V}))$. Each of the identified spots was scraped off from the plate and dispersed in a counting vial containing $1 \mathrm{ml}$ of $0.1 \mathrm{~N} \mathrm{NH}_{3}$ in ethanol. One tenth $\mathrm{ml}$ of $5 \%(\mathrm{WV}) \mathrm{Na}_{2} \mathrm{~S}_{2} \mathrm{O}_{3}$ in ethanol-water $(1: 1(\mathrm{~V} / \mathrm{V}))$ was added to decolourize the mixture and the radioactivity was measured as described previously.

All experiments including the measurements of enzyme activities as well as choline uptake were carried out at $\mathrm{pH} 6.8$ to prevent the decomposition of added parathion. Parathion and DFP were added into various test systems after suspending with propyleneglycol.

\section{RESULIS}

Effect of parathion and DFP on (hAC artivitie's

In the brain homogenate and synaposomal fractioms DFP (0.01 10 mM) had no significant effect on ChAc activity, whereas patrathion (1 $10 \mathrm{mM}$ ) showed a dose-dependent 


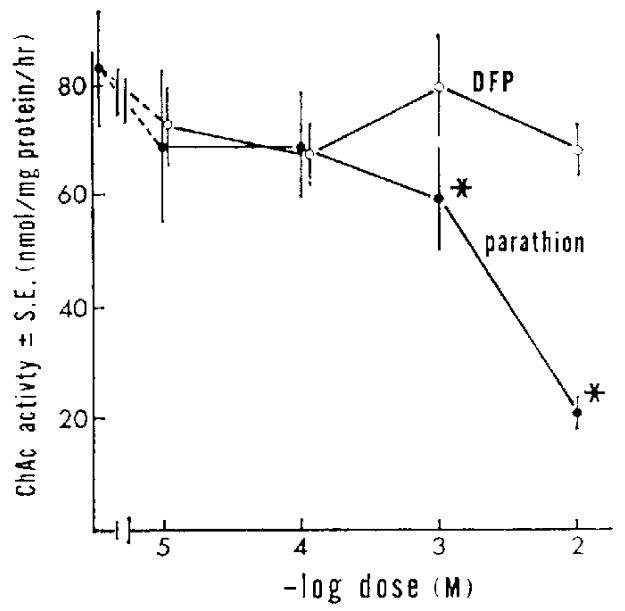

FIC. I. Effect of parathion and DEP on ChAc activity in brain homogenate $*$ p. 0.05 , Compared with control value.

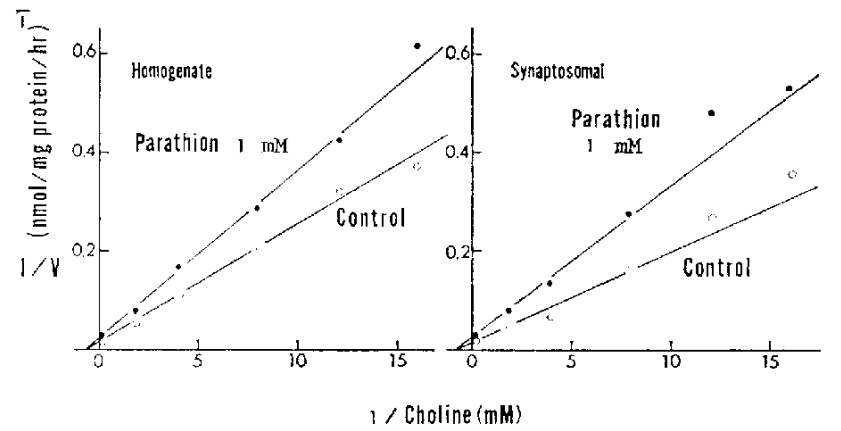

Fic. 2. Eftect of parathion on Lineweaver-Bulk plots of ChAc activity in brain homogenate and synaptosomal fraction.

homogenate: $\mathrm{Km}=1.43 \mathrm{mVM}, \quad$ synaptosomal: $\mathrm{Km}=1.81 \mathrm{mM}$

inhibition on ChAc activity (Figs. 1 and 2). As shown in Fig. 2, this inhibitory effect of parathion was non-competitive.

In preparations of homogenate, microsomal and synaptosomal fractions the highest AChE activity was found in microsomal fraction and the lowest activity was found in synaptosomal fraction. These results are essentially in good parallel with previous reports (11). In these fractions the $0.05 \mathrm{mM}$ of parathion and DFP inhibited significantly AChE activity. The inhibitory effect of DFP on AChE activity is reportedly stronger than that of parathion (12). In addition, parathion $1 \mathrm{mM}$ had no significant effect on the activities of MDH and $\mathrm{LDH}$ assayed in the brain homogenate. These results suggest that the inhibitory effect of parathion on ChAc activity may not be a simple reflection of the effect of this compound on general enzyme proteins.

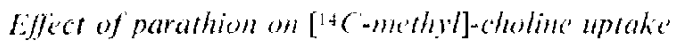

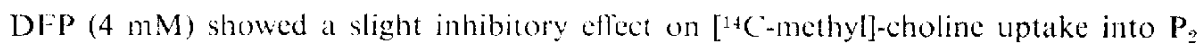


fraction, but this inhibitory effect was not statistically significant. On the other hand, parathion $(4 \mathrm{mM})$ inhibited significantly the choline uptake (Table 1). At the range of $\left[{ }^{14} \mathrm{C}\right.$-methyl]-choline concentrations of 2.5-25, $: \mathrm{M}$, parathion showed apparently competitive inhibitory elfects on the choline uptake (Fig. 3).

As shown in Table 2, the inhibitory effect of parathion ( $1 \mathrm{mM}$ ) on the choline uptake was detected at $37 \mathrm{C}$, but was not observed at $0^{\circ} \mathrm{C}$. These results indicate

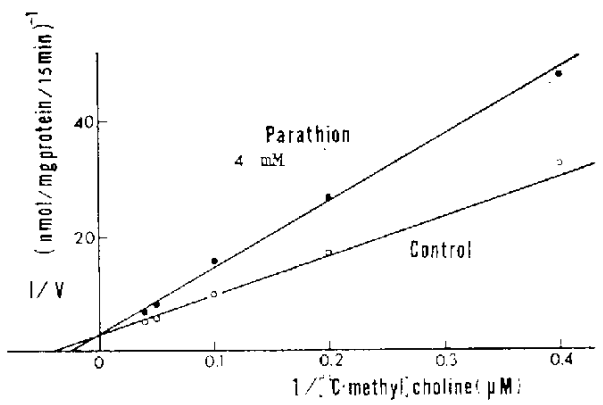

Fic. 3. Effect of parathion on [1+C-methyl]choline uptake into crude mitochondria! fraction.

$\mathrm{Km} \cdots 26.8 \mu \mathrm{M}, \quad \mathrm{Ki} \quad 42.7 \mu \mathrm{M}$

that parathion has inhibitory effects on temperature and possibly energy dependent processes of the choline uptake.

Effect of parathion on ACh synthesis

Following the incubation at $37^{\circ} \mathrm{C}$ for $15 \mathrm{~min}$ of $\mathrm{P}_{2}$ fraction with $\left[{ }^{14} \mathrm{C}\right.$-methyl]-choline, both $\left[{ }^{14} \mathrm{C}\right.$-methyl]-choline and $\left[{ }^{14} \mathrm{C}\right.$-methyl]- $\mathrm{ACh}$ extracted from the incubation mixture

TABLE 1. Effect of organophosphorus compounds on $\left[{ }^{1+} \mathrm{C}\right.$-methyl]-choline uptake into crude mitochondrial $\left(P_{2}\right)$ fraction of mouse brain

\begin{tabular}{|c|c|c|}
\hline \multirow[b]{2}{*}{ control } & \multicolumn{2}{|c|}{$\begin{array}{c}{\left[{ }^{1+} \text { C-methyl]-Choline Uptake }\right.} \\
\text { (p mol/mg protein'min) }- \text { S.F.M. }\end{array}$} \\
\hline & parathion $4 \mathrm{mM}$ & DFP $4 \mathrm{mM}$ \\
\hline $195.9 \cdot 23.3$ & $117.8 \cdot 20.0^{* *}$ & $173.5 \cdot 13.6$ \\
\hline
\end{tabular}

The mean - S.E.M. obtained from four separate experiments.

The incubation medium contained $10 \mathrm{n}$ mol $\mathrm{ml}$ of $\left[{ }^{14} \mathrm{C}\right.$-melhyl]-choline and $2.2-5.9 \mathrm{mg}$ protein of $\mathrm{Pe}$ fraction.

$\because p-0.05$. Compared with control value.

TABLE 2. Effect of parathion on uptake of $\left[{ }^{1} \mathrm{C}\right.$-methyl]-choline by crude mitochondrial $\left(\mathrm{P}_{2}\right)$ Pracion at $0 \mathrm{C}$ and $37 \mathrm{C}$

\begin{tabular}{|c|c|c|}
\hline & $\begin{array}{c}\text { Pellet }(\mathrm{P}) \\
\text { (p molmy protein of } \\
\mathrm{P}_{2} \text { fraction } 15 \text { min) }\end{array}$ & $\begin{array}{c}\text { Supernatant }(\mathrm{S}) \\
\text { (n molimg protein of } \\
\text { Pa fraction } 15 \mathrm{~min} \text { ) }\end{array}$ \\
\hline $0 \mathrm{C}$, control & $74.7 \cdots 1.6$ & $2.77: 0.10$ \\
\hline $\begin{array}{l}\text { I parathion } \\
1 \mathrm{mM}\end{array}$ & 76.26 .5 & $2.78 \quad 0.14$ \\
\hline $37 \mathrm{C}$, control & $153.2 \cdot 9.9$ & $2.76: 0.06$ \\
\hline $\begin{array}{l}\text { parathion } \\
1 \mathrm{mM}\end{array}$ & $115.2 .9 .2:$ & $2.72 \quad 0.05$ \\
\hline
\end{tabular}

The neath S.l V. whatined from three separate experiments.

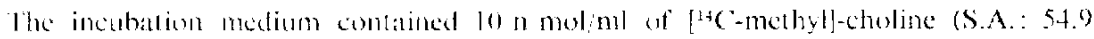
mCim mol) and 2.73 .4 me protein of $P_{2}$ fraction.

$*$ p. 0.01 , Compared with control value. 
TABLE 3. Effect of parathion on acetylcholine synthesis in crude mitochondrial $\left(\mathbf{P}_{2}\right)$ fraction at $37^{-} \mathrm{C}$

\begin{tabular}{|c|c|c|c|c|c|}
\hline \multirow[b]{3}{*}{ pellet } & \multirow{4}{*}{$\begin{array}{l}\text { control } \\
+ \text { parathion }\end{array}$} & \multicolumn{2}{|c|}{ (p mol/mg protein $/ 15 \mathrm{~min}$ ) } & \multirow{2}{*}{$\begin{array}{c}\text { Conversion } \\
\text { Rate(CR) } \\
\text { (ACh } \times 100 \\
\text { choline } \mathrm{ACh} \text { ) }\end{array}$} & \multirow{2}{*}{$\begin{array}{l}\text { Change in } \mathrm{CR} \\
\text { (\% Inhibition) }\end{array}$} \\
\hline & & ${ }^{14} \mathrm{C}$-choline & ${ }^{14} \mathrm{C}-\mathrm{ACh}$ & & \\
\hline & & $92.3+10.3$ & $29.4 \cdot 4.2$ & 24.2 & \\
\hline & & & & & \\
\hline \multirow{5}{*}{ supernatant } & $\mathrm{mM}$ & $84.5 \div 8.5^{*}$ & $18.7 \div 7.5^{*}$ & 18.1 & 25.7 \\
\hline & $4 \mathrm{mM}$ & $76.0 \pm 8.2^{*}$ & $14.7: 3.4^{* * *}$ & 16.2 & 32.9 \\
\hline & $\begin{array}{l}\text { control } \\
\text { - parathion }\end{array}$ & $3012.1 \perp 390.3$ & $102.1 \div 12.3$ & 3.4 & \\
\hline & $1 \mathrm{mM}$ & $2959.9 \div 416.5$ & $97.7 \doteq 6.3$ & 3.3 & 2.5 \\
\hline & $4 \mathrm{mM}$ & $2895.2 \pm 359.4$ & $79.9 \div 12.6$ & 2.7 & 18.1 \\
\hline
\end{tabular}

The mean $=$ S.E.M. obtained from four separate experiments.

The incubation medium contained $10 \mathrm{n} \mathrm{mol} / \mathrm{ml}$ of $\left[{ }^{14} \mathrm{C}\right.$-methyl]-choline ( $\mathrm{S} . \mathrm{A} .: 54.9 \mathrm{mCi} / \mathrm{m} \mathrm{mol}$ ) and 2.3-3.7 $\mathrm{mg}$ protein of $\mathbf{P}_{2}$ fraction.

$* \mathrm{p}<0.05, \quad * * \mathrm{p}<0.02$, Compared with each control.

were analyzed by a thin layer chromatographic procedure.

More than $90 \%$ of the radioactivity was recovered as $\left[{ }^{14} \mathrm{C}\right.$-methyl]-choline and $\left[{ }^{14} \mathrm{C}\right.$ methyl]-ACh.

In pellet fractions, the conversion rate (expressed as $\mathrm{ACh} \times 100 /$ choline $+\mathrm{ACh}$ ) for control was 24.2 , whereas rates for $1 \mathrm{mM}$ and $4 \mathrm{mM}$ of parathion were 18.1 and 16.2 , respectively (Table 3 ). These results clearly indicate that parathion has inhibitory effects on ACh synthesis. In supernatant fractions, the conversion rate for control was 3.4 and showed a tendency to decrease with addition of parathion, but these effects were not statistically significant.

\section{DISCUSSION}

One of the most interesting findings in this study is that parathion, which has been classified as one of ChE inhibitors and known as an organophosphorus compound, also has inhibitory effects on the activity of $\mathrm{ChAc}$ and on the uptake of choline into brain subcellular fractions. The extent of inhibitory effects of parathion on the ACh synthesis in the brain tissues was larger than the inhibitory effects on ChAc activity or on the choline uptake, suggesting that the inhibition of ACh synthesis by parathion may be a reflection of the inhibitory effects of this compound on both parameters. Hanin et al. (1) suggested the possibility that cholinesterase inhibitors used at high concentrations do not affect the steady state of ACh solely by inhibiting ChE, but inhibitory effects of these compounds on choline uptake might also be involved as one of the main control mechanisms. On the other hand, Kobayashi et al. (2) reported that DDVP, an anti-AChE agent, diminished ACh synthesis by inhibiting ChAc activity. Our results indicate that parathion has inhibitory effects on both ChAc activity and choline uptake, simultaneously.

Parathion and DFP have long been classified in the same category as organophosphorus ChE inhibitors. These compounds, however, have a different effect on ACh synthesis; 
Parathion inhibits ACh synthesis in the brain tissue, while DFP has no such a property. It is well documented that neurotoxic effects of parathion are generally lower than DFP (15), possibly due to the weaker inhibitory effect of the former compound on ChE activity than the latter. However, if we consider differential effects of parathion and DFP on ACh synthesis, another possible factor may also be added to explain these differences: Parathion inhibits both $\mathrm{ChE}$ and $\mathrm{ACh}$ synthesis, and thus the increase of $\mathrm{ACh}$ in ncuronal tissues, the agent which plays a main role in neuronal toxicity of these compounds, is lower in the case of parathion than DFP. The concentration of parathion required to exhibit inhibitory effects on ACh synthesis is undoubtedly higher than that required for the inhibition of ChE. Although the significance of inhibitory effects of parathion on ACh synthesis via inhibitions of ChAc and choline uptake in terms of pharmacologic actions of this compounds is uncertain, it must be emphasized that not only the well known inhibition of ChE activity, but also the inhibitory effects on $\mathrm{ACh}$ synthesis must be considered when a high dose of parathion is used.

Recently stryptoridine analogues have been introduced as a potent ChAc inhibitor (13). These compounds also inhibit ChE activity at relatively high concentrations, and there is a hypothesis that both esterase and acctylase have similar functional groups to combine with these agents (14). Similar mechanisms may be involved in the inhibitory effects of parathion on both $\mathrm{ChE}$ and ChAc activities.

Acknowledgement: This work was supported in part by research grant (No. 987015, 1974) from the Ministry of Education, Japan.

\section{REFERENCES}

1) Hanin, 1., Massarelli, R. ayd Cusia, E.: Adr. Biochem. Piychopharmacol. 6, 181 (1972)

2) Kobayashi, H., Yuyama, A. and Matsusaka, N.: Folia phamacol japon, 67, 47 P (1973) (in Japanese)

3) Gray, E.G. and Whin'lakir, V.P.: J. Anat. 96, 79 (1962)

4) Fonnti, F.: Biochem. I. 115, 465 (1969)

5) Ellman, G.L., Colnjini, K.D., Andres, V. avd Featherstone, R. M.: Biochem. Phamacol. $7,88(1969)$

6) Bergimerek, H.V., Bernet, E. And Hess, B.: Wethod of Enzymatic Analysis, p. 738 Academic Press. New York (1963)

7) Mehler, A.H., Kornberg, A., Grisolia, S. and Ochoa, S.: J. biol. Chem. 174, 961 (1948)

8) Toru, M. and Aprison, M.H.: J. Nelrochem. 13, 1533 (1966)

9) Marcilbanks, R.M.: Biochem. J. 110, 533 (1968)

10) Lowry, O.H., Rosebrough, N.J., Farr, A.L. and Randall, R.J.: J. biol. Chem. 193, 265 (1951)

11) WhitTaker, V.P., Michaelson, I.A. ANd Kirklavd, R.J.: Biochem. ./. 90. 293 (1964)

12) Holmstedt, B.: Pharmacol. Rev. 11, 567 (1959)

13) Carallito, C.J., Yun, H.S., Kaplan, T., Smith, J.C. and Foldes, F.F. : J. med. Chem. 13, $221(1970)$

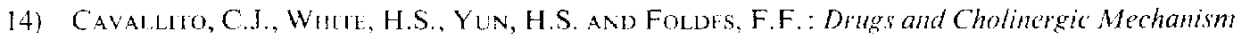
in the CNS. Edited by HeIlBRONiv, E. AND WINTER, A. Research Institute of National Defense. Stockholm, Sweden, p. 97 (1972)

15) Goldostin, A., Arovow, L.., and Kalman, S. M.: Principles of Drme Acrion. Harper and Row Publishers, New York p. $394(1969)$ 